\title{
研究論 文
}

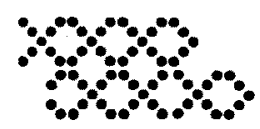

\section{6. 制御系ロジック自動変換方式}

\author{
和田 裕*, 小林 康弘*, \\ 三代庸正**, 岡野正人**
}

(1989年6月13日受理), (1989年 11月20日再受理)

\author{
Automated Logic Conversion Method for Plant Controller Systems
}

By Yutaka WADA, Yasuhiro KOBAYASHI,

Tsunemasa MIYO and Masato OKANO

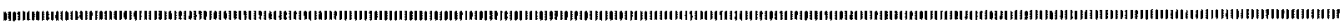

An automated method is proposed for logic conversion from functional description diagrams to detailed logic schematics by incorporating expertise knowledge in plant controller systems design.

The method uses connection data of function elements in the functional description diagram as input, and synthesizes a detailed logic structure by adding elements to the given connection data incrementally, and to generate detailed logic schematics.

In logic synthesis, for building up complex synthesis procedures by combining generallydescribed knowledge, knowledge is applied by groups. The search order of the groups is given by upper-level knowledge. Furthermore, the knowledge is expressed in terms of two classes of rules; one for generating a hypothesis of individual synthesis operations and the other for considering several hypotheses to determine the connection ordering of elements to be added. In the generation of detailed logic schematics, knowledge is used as rules for deriving various kinds of layout conditions on schematics, and rules for generating two-dimensional coordinates of layout objects. Rules in the latter class use layout conditions to predict intersections among layout objects without their coordinates being fixed.

The effectiveness of the method with 150 rules was verified by its experimental application to some logic conversions in a real power plant design. Evaluation of the results showed them to be equivalent to those obtained by well qualified designers.

KEYWORDS: knowledge based component, logic conversion, functional description, logic schematics, diagrams, design, plant controller systems, rules, layout condition

\section{I. 踷言}

原子力発電ブラントは，各種設備を中央制御室から 監視制御する方式を採用した典型的な大規模ブラント である。電力の安定供給のため,より一層の安全性向 上および肩頼性向上を図る努力が続けられている(い。 特に，信賴性向上のために制御系を圥长化，多重化す る上で，従来のフナロク装置では解决が困難であった 監視制御設備の高速化，大容量化の課題に対し、デシ タル制御技術が有効に活用されている。ナなわち，制
御系の機能は，最終的な製品形熊としてンフトウェア で実現されるすのの割合が增加しつつある。このよち な背景の中で, 制御係設計の過程での、ソフトウェフ の開発,検証および健全性確認のための管理手法の重 要珄が認識されつつある(2)(9)。

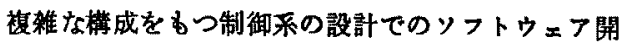

* 日立作所エネルギー研究所 (Energy Res. Lab., Hitachi, Ltd.)

**揀日立䌘作所大みか工場 (Oomika Works, Hitachi， Ltd.) 
発は,計画設計からら詳細設計へと段階的に進められる。 設計の各段階では，制御系の構成を検討するために， 系珫の種類や取り扱ら信号の種類に応し，計装制御系 やシータンス制御系などの機能的な単位ごとに，定め られた様式に従った圂面を用いているいこれらの図 面の多くは，ファンクションブロック図(FBD; Function Block Diagram)と総称される様式に従っている。 ここで，設計者は，計画設計で得られた機能図に含ま

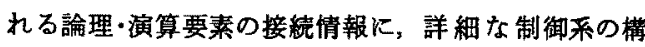
成を决定するための情報を付加し，詳細設計で用いる 困面の様式で線図を作図する，いわゆるロシック変換 を行なっている。

制御系の機能を実現するンフトウェアの高信頼性を 確保するためには，一定の規則や基準に従ってロシッ ク変換がなされるように，計算機により設計を支援す ることに意義がある。

現在，機能図，詳細図の製図には，クラフィック表 現能力を持つ計算機支援設計システム(5) (7)の利用が進 められている。さらに，詳絊図を基に，(1)演算要素の ゲインや時定数などの計装制御バラメータの最適値を 設定するための計装制御系CADシステム(8)，(2)制御用 マイクロプロセッサで論理・演算処理動作を実行可能 とする制御演算ブロクラムを生成するためのソフトウ エア生差支援ツール盟等が整備されつつある。

このよ5に，詳細設計段階での計算機化の研究開発 が着実に進められているのに対し，譏能図から詳細図 ヘのロショック変換に関しては，設計者を有効に支援す る計算機謤境がほとんど実現されていなかった。制御 系設計業務の中でもロジック変換の部分は，熟練した 設計者が持つ専閏的な知識や判断に依存するところる 大きいため，従来の数值フルゴリズムによる計算機の 利用方法では，対応が難しい状況にあった。

すでに，半学体集積回路を対象とした論理回路設計 の分野では，回路の機能構成を与える機能园を半導体 素子単位で結線情報を表わす回路図にロシックを変 換する磨に，変換規則や設計基集を知識として利用し 自動化を図る技術がある(11) (1a)。さらに，数值的な制 御の反映を中心とした回路図のレイアウトの手順は， アルコリズムにより実現されている(14)(15)。

しかし，制御系のロシック变换は，以下の点で半㫷 体論理回路のロシック变換の形態と知識の使い方が異 なり，従来の手法を直接谪用することができない。

(1) 単に機能図に含まれる要素を，より詳細な接 精情報に展開するのではなく，機能罒では省略 されていた要素を付加する。
（2）機能図と詳細図の表現形式が全く異なること から，機能图の配價情報が汪とんど利用できな W。

本報では，制御系設計に特有なロシック变換のプロ セスを自動化するに適した知識処理方式(18)と，それ を応用した制御系ロシック自動变換システムについて 報告する。

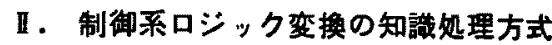

本章では，発電ブラント制御系設計で用いられる园 面を例としてロジック变換方式を記述する。機能図 として制御系統図和よび拍作ブロック図を，詳細図と して制御ロシック図を和のおの対象とした。これらの 図面はFBDの形式で作成されている。制御系統図は， フナロク量の数值演算,デシタル量によるてナログ量 の切換え制御を中心とした計装制御系の機能仕様を記 述したものである。操作ブロック罒は，インタロック 操作などのデシタル量の論理演算を中心としたシーケ ンス制御系の機能仕様を記述したすのである。

第 1 図に，計装制御系のロジック設計の流れとロシ ック変換の位置付けを示す。計画設計により与兄られ

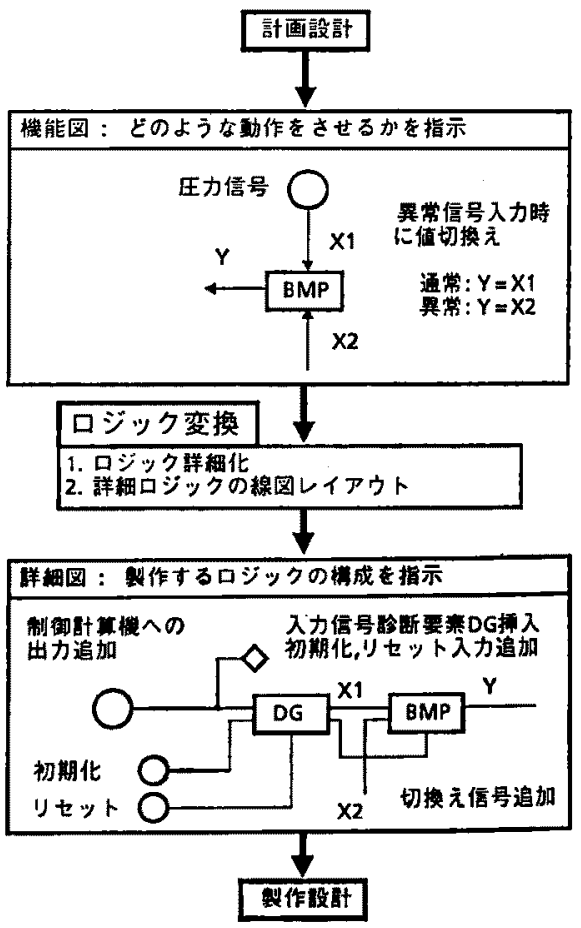

第 1 図制㣁系ロジック設計の流れと ロシック变換の位置付け 
る機能因は，制御系にどのような動作をさせるかを指 示するすのである。本俔では，「仼力信号の測定值に 異常があれば，信号入力值を切換 兄る」ととを指示す るため, 壬カセンサ, 信号切換え要素を接繶したブロ ック四形式で表わしている。ロジック変換の結果得ら れる詳練図は，機能を実現するために製作する制御演 算ブログラムの処理構成を指示する。

1. ロジック詳梱化での知識処理方式の課题

第 1 四の例では，設計者は压カセンサ,信号切換党 要素の接続関保江注目し，(1)信号测定值の訩断要素の 揮入，(2)診断要素の初期化，リセット，切換文信号線の 追加，(3)信号測定值を制御計算機へ取り込む端子の追 加により、ロシックを詳細化している。

詳細化の操作を単位とする形で知識を表現すると， 複数の知識の条件が同時に満たされ，どの知識を先に 通用するかを判断する必要が生しる。詳細化の過程で 变化する要素の接続バタンを要素単位で探索する形で 知識を表現すると，類似した条件部と共通の結論部を 持つ知識が多数生し，知識の関連を意識する必要があ る。

一方，広い範用の要素の接続ハタンに対応して，一 度に多数の要素を付加するよらに知識を表現すると， 推論の単位となる知識の規模(grain size)が大きくな るため，知識に沉用性と払張性を持たせるという知識 ベースシステムの長所が損なかれる。したがって，設 計者の知議を汎用な形で生かすといら観点からは，一 般的な形で知識を与克ると，詳細化の過程でそれらが 組み合わされ，各接綂パタンに特有な詳細化手順が满 成されることが望ましい。知識の規模を小さくするた め飞は，順序関伯を反映して，知識を棈造化し適用す る知識の範囲を限定する処理が不可欠である。この手 法では，推論の特徽と知識の構成に応して知識をクル ーブに分割ナる方法を考麀し、クルーブ内の知識の競 合解消を図る必要がある。

2. ロジック詳細化での知鿁処理方式

(1) 知識の構成

a. 知識のグルーブ化

前述したように，詳細図の要素は，制御演算ブロダ ラムの実行単位に対応している。実行単位は, マイク ロプロセッサで実行される演算命令を組み合わせだ フルーチンの形で実現されている。これは、サブルー チンの粠成変更やバラメータの調整によって, 制御系

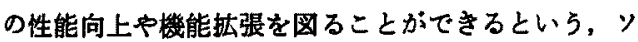
フトゥェての利点を生かすためである。したがって， 機能図では単に機能的な意味を与えるるのであった要
素の入出カデータ纥, 詳細図では, 演算命令の入出力 データの形式や值城などに依存した仕様が与えられる ののとなっている。

要素間で入出カデータの仕様が異なる場合には，デ 一タ間の整合をとるために, データ值の規格化や值域, 堛减率の限定など，制御の特性を变化させることが詳 細化の目的の 1 つになっている。また，制御系の安定 な動作を確保するために, デー夕值の值域，增減率の 限定を初め，データが巽常值をとった場合の例外処理 の付加や，入力として用いるデータを切り換えるなど， 演算条件を変化させることる詳緗化の目的とされる。 これらの目的のためには，機能図の要素内のサブルー チンに演算命令を追加することは避けて，新たな要素 を組み合わせて機能図に追加することが，要素の沉用 性を確保する上で有效な詳細化の手段となる。

また，大規模な制御系では，異なる機能を多数の系 統に分割して同一の機能を多重系統で冗長に構成する 設計が多用される。したがって，複数の詳細図の間で 同一のデータを利用するための制御信号の分岐を設け ることが詳細化の目的となる。

さらに，詳細化の過程で制御信号の特性に变化が生 し，機能図での分岐の位置からは直接制御信号が利用 できなくなる状況では，特性に変化が生じる前の制御 信号を選ぶことが必要になる。

以上のように，プロック図形式で表わされた機能図 のロシックを詳細化する目的と手段に注目すると，口 シックを付加する一連の操作は, 次の 3 点の組合せと なっていることがわかった。

（1）制御信号の特性や演算条件を変化させるため に，要素を追加する。

（2）制御信号の特性等を変えずに利用するため

に，接続線の分岥中要素を追加する。

（3）利用する制御信号を変えるために，分岐の位 貣を变更する。

第 1 因の例では，訅断要素DGの挿入は(1)に対応し， 制御計算機への出力追加は(2)に対応する。

以上よりロジック詳細化の知識をタループに分割 する基準は，ロジック詳勫化の目的の锶点から上記の (1)〜3)とした。また，複雑な後㞍り処理を回避すると いら観点からは，(1)と(3)により与光られる最終的な詳 紐図で用いる制御信号の特性等を反映して(2)を行らこ とが有効である。

さらに，基本的に設計者は，制御系の詳細図が機能 四の要素の接続関係を継承するように，機能図を参照 している。したがって，機能図に対し無条件に分忮位 
璱の変更が生じることになく，なんらかのロジック詳 細化の結果に付随して分吱位置が変更される。このよ 5に，図面情報の特徽から，必然的に(1)は(3)に優先す ๖。

以上のよ5に，知識のクルーブ間の適用順序は(1)， (3),(2)とすることが,効率的な詳細化手湏を構成する上 で不可久である。

b. 知識の表現

詳細化手順は，譏能図の要素の接続情報の中から詳 細化の操作を適用する部分を抽出し，その部分に対し 必要な要素の付加等に伴う接続情報を変更し,さらに 次選択する詳細化の提作を求めるという処理を繰り 返すすのである。したがって，各操作は単一の要素に 固有なすのでなく，複数の要素間の関係を認識して与 えられるるのとなっているので，各知識のグルーブ 属する下位の知識は，If $\cdots$, Then *形式のルールで表 現する。

下位の個ふの知識の単位としては，詳細化による要 絜の接続関係の変更に際し，追加する椱数の要素等の 接続順序が結論として与えることができる条件ごとに 分割するあのとした。これには，単一の要素の迫加や 分伎位直の变更も含まれる。

さらに，グルーブ内での知識の競合を解消するため に，知識を次の 2 段階のルールに分䧹して表現する。

(1) 要素の接続関㐿に基づき，詳細化のために追 加する複数の要素と変更する要素との接続関係 を仮説として求めるルール。

(2) 共通の接続構成に対して与えられた複数の仮 説似基つき，追加する要素等の接繶順序を決定 し，要素の接続関係を変更して詳細化の結果を 反映するルール。

(2)には，単一の仮説のみを参照して，接続関係 を変更するルールも含む。

ここで(2)のルールは，(1)のルールで得られた仮説を 参照するため，(1)のルールから適用される。さらに， (1)のルールでは，すでに得られた詳細化の結果を策件 として判定する知識す記述する。推論では，詳細化の 過程で変化する要素の接綂情報に対し，クルーブ内の すべての知識の適用可能性を㭘㚗し，仮説が生成され なくなるまで，(1)，(2)のルールを繰り返し適用する。 その結果，あるクルーブでの知識を用いた推論が終了 した段階で得られた要素の接続情報に対しては，るは やそのグルーブ内の知識は成立しないすのとなる。

このような 2 段階のルールで楼成した理由は，仮説 を生成するための条件と，仮説を比較して接続順序を
判定して競合を解消するための条件とを分離すること により，汎用性の高いルールの記述ができるからであ る。

第 2 四に，要素を择入する知識を 2 段階のルールに 分碓して表現した例を示す。

\section{知識の例}

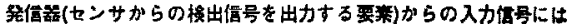
制要秦を骦入する
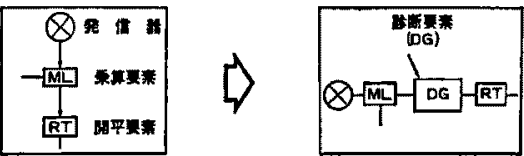

\section{ルールの表現 \\ 1.仮説を与えるルール; $\mathrm{A} ; \mathrm{B}$ は变数。「」は仮説。

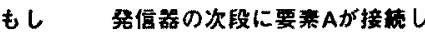 要赍Aの次段に要寒Bが接镜している ならば「要秦AとBの间に喰断要絭 DGを抒入する

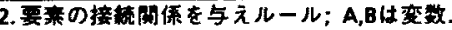

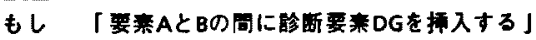 \\ ならば（1)捅入する要慗のデータ生成(DG-1とする)

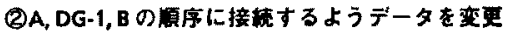

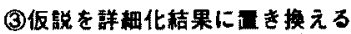 詳細化結果:「要秦AとBの间にDG-1を拥入した}

第 2 图ロジック詳細化の知識の例

知識のタループ間の適用順序を記述し，検索するル ールの範囲を限定する上位の知識も，次に示すような 単純な関係の記述であり、ルールと同様の形式のメタ ルールで表現する。

[メタルール]

もしロジック詳紐化のブロセス開始

ならば 以下の順に，知識のタルーブを適用

(1)要素の挿入

(2)分岐の位置の変更

(3)分岐と要秦の追加

以下に，上記の考え方に基つき構成するルール内て の条件や結論の記述に適した要素,詳細化の仮説·結果 の各表現について説明する。

(i) 要䍊の表現

要素の情埌はフレームにより表現した。フレーム は，一種のテーブル形式により，属性とその值とを対 応させて記憶するすのである。属性とは，要素の種 類、入出力端子の名称等である。フレームは，属性を 指定してその值を検索するのに遒しているのて，特に 
ルールの条件部で，要素間の接続関係をバタンとして 抽出する上で有効な表現である。

（i）詳細化の仮説・結果の表現

詳細化の仮説・結果に関する喈報は，要素のデータ とは独立した形式で，要素間の関係をイベントとし て述語論理型データにより直接表現した。

詳細化の仮説を要素の接続情報の上に反映された形 で扱らと，機能図に元からあった要素と新たに付加し た要素とを区別する情報を要素の情報に持たせなけれ ばならない。しかし，個々の要素のデータにこの関俰 を組み込をと，䄈数の要素のデータを梌索する必要が あり効率が悪い。さらに，1つの要素に対して複数の 詳細化が関与した場合，個々の詳細化による接続情瓡 の変化を捉えることが困難となる。そこで，詳細化結 果は，「要素Aと要素 $\mathrm{B}$ の間に新たな要素Cを挿入す る」, 「要素 $\mathrm{X} の$ 出力から要素 $\mathrm{Y} へ$ の分歧を要素 $\mathrm{Z}$ の出 カへ変更する」等の形で表現されたイベントとして报 えることが望ましい。

すでに得られた詳細化の仮説・結果に传存した他の 知識の商用条件を效率的に判定するため，詳細化によ る接続情報の変化を值接表現することが可能となる。

(2) 推論方式

第 3 図に，ロジック詳細化での推論方式の概要を示 す。知識のグルーブ間の適用順序は上位の知識により 与える。各グルーブ内での知識を適用する際には，新 たな仮説が得られなくなるまで，以下の手順を稆り返 广。

（1）推論の対象範囲を仮説を求めるルールに限定 し，要素の接続パタンを探索して仮説を求める。 この段階では要素の接続情報を变更しない。

(2) 推諭の対象範囲を要素の接続順序を与えるル 一ルに限定し，仮説を反映して要素の接続関係 を変更する。反映された仮説は詳細化結果とし て登淾する。

(3) (1)に㞍り，すでに得られた詳細化結果に恢存

して必要な詳細化の操作を進める。

ここで，(2)では，複数の仮説を条件にもつルールを 影先的に探索するため，条件部で条件の多いルールか ら道用する。さらに，一度反映された仮説は，再び他 のルールの条件を满足させることがないようにした。 これは，一部の仮説のみを用いた局所的な詳細化結果 を与えるルールが先に暗用されることを回避し，得ら れた中からより多くの仮説を考虔するルールを優先す るためである。

以上のようなルールの探索戦略を用いることによ

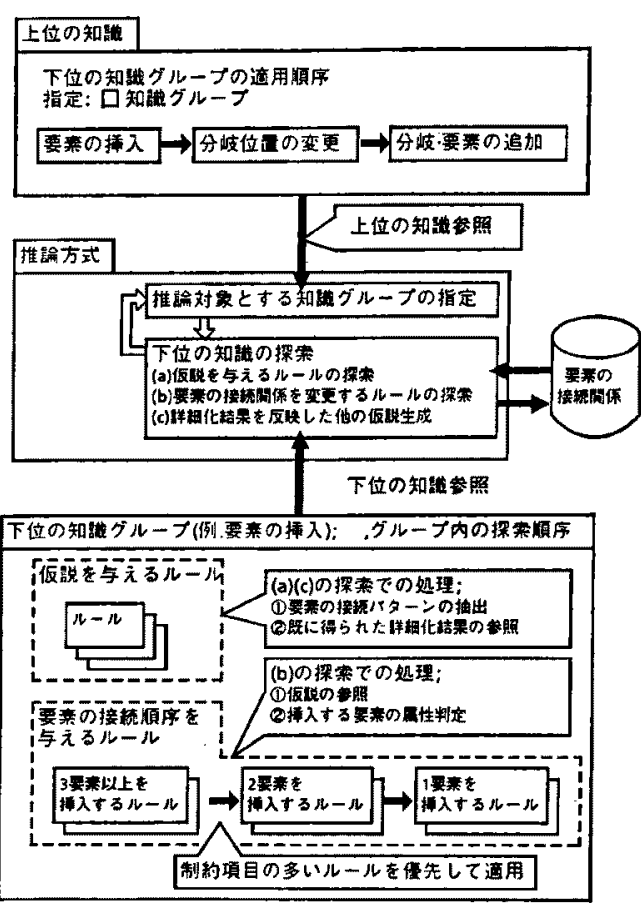

第3图ロシック詳細化の推論方式

り, 数数の詳緗化の操作が要素の接絸関係に反映され た結果を個別に蓄えたり，それらを比較して不要な結 果をバックトラックにより削除するなとの缼雑な好理 が避けられる。

(3) ロジック詳細化のブロセスの例

a. 上位の知識による下位の知識の適用順序の制御 計装制御系のロジック変換での，上位の知識による 下位の知識の適用順序の制御例を説明する。

第 4 图に，誩断要素を 1 個所に挿入する一連の口ジ ック詳細化のブロセスを示す。本例では,要素の捜入， 分秓位首の变更, 要素の追加のおのおのに成するすの に分割した下位の知識の中から，以下のるのを選択し て適用する。

(1) 診断要素の垀入

(2) 制御計算機への出力端子の分伎位睓の変更

(3) 入出力端子の追加

(2)では（1)の知識の適用結果を接続情報の変化とし て利用することにより，前段階で得られたロシック詳 細化の結果を反映する必要がある副次的なロジック詳 細化の条件を判定している。(1)の知識により㨉入され た診断要素は, その入力値が異常の場合，その出力値 を一定値に保持する機能がある。したがって，異常值 


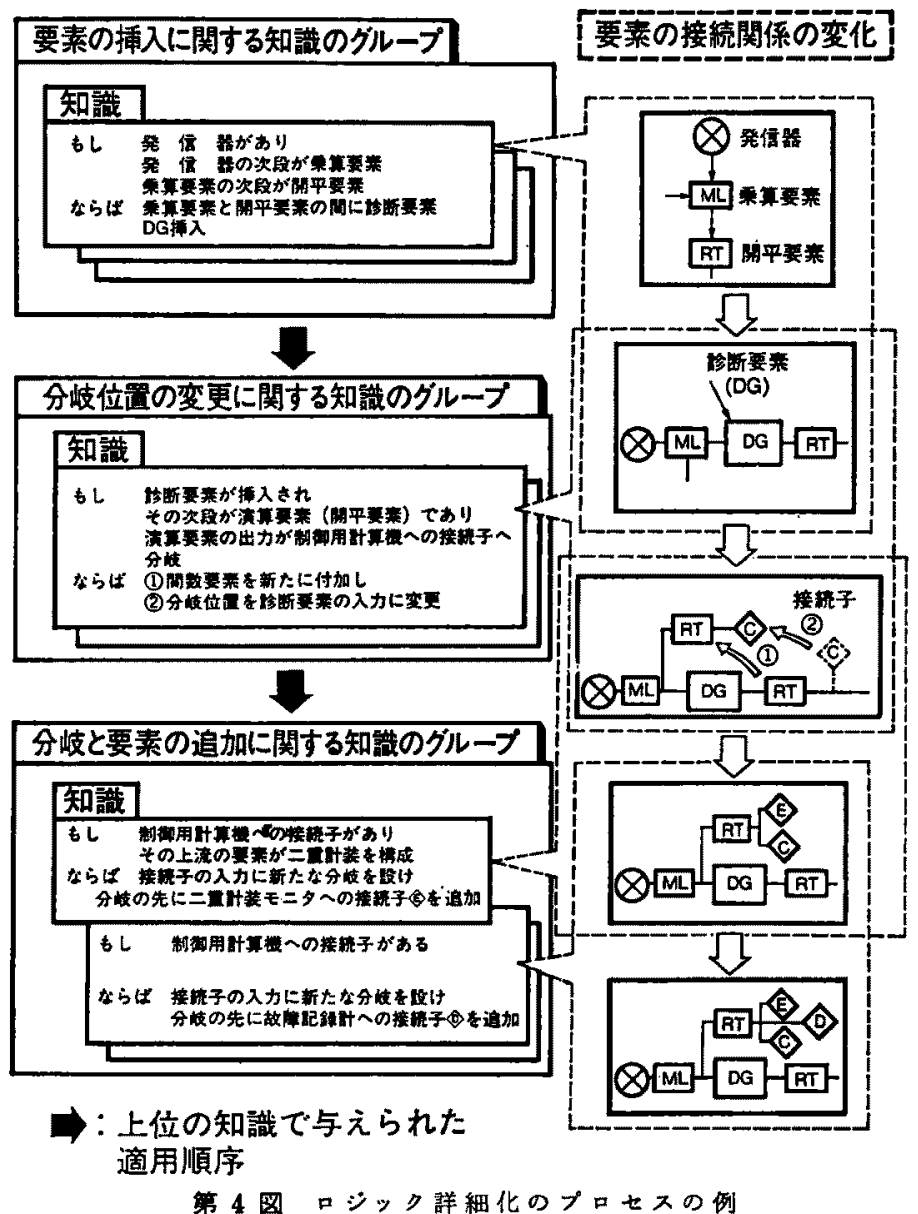

の入力後に制御計算機で監視を継続するためには，診 断要素への入力值を監視する制御信号値として取り出 すための副次的な詳細化が必要となる。

\section{b. クループ内の知識間の競合の解消}

同一の要素の接続構成に共通した複数の仮説が成立 し，仮説間の競合を解消するルールを段階的に適用し たブロセスを，第 5 図に示す。本例は、シーケンス制 御系のロジック変换の例である。

まず，「起動命令の入力端子と，その次段飞既接繶

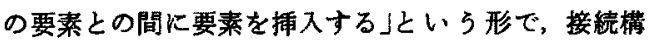
成の変化を仮説として求める。ここでは, 以下の要素 を挿入する仮説が得られている。

(1) 自動化条件のインタロック(AND要素)

(2) イミング協調のタイマ(TD要素)

次に，複数の仮説を参照し，捜入する要素の接続順 序を決定するルールが適用されれるここでは，同一の
要素の接綂搆成(起動命令の入力端子と次段の OR要 素)間に，2 種類の要素(AND と TD)を挿入する条件 に着目したルールを適用する。このルールでは，新た に要素を揮入する周囲の接続構成に依存せず，「TDを 最る出力に近い位䁂に㨉入し，その前段に他の起動条 件のインタロックを㧴入する」条件のみを反映してい b。

3. 線図レイアウトての知護処理方式の課要 半复体論理回路の設計では，回路素子間の接続関係 と論理段とに注目した論理楊成の確認を目的として回 路図が用いられる。ここでは，機能图の機能要素の眍 固情報を利用して回路素子を配置し，機能图と眍置を 対応させて回路図が見易く搆成されていることに重点 が置かれている。したがって，半辛体論理回路图の線 因レイフウトでは，数值的な配置条件を主炕考虑した フルコリズムが可能となっている。 


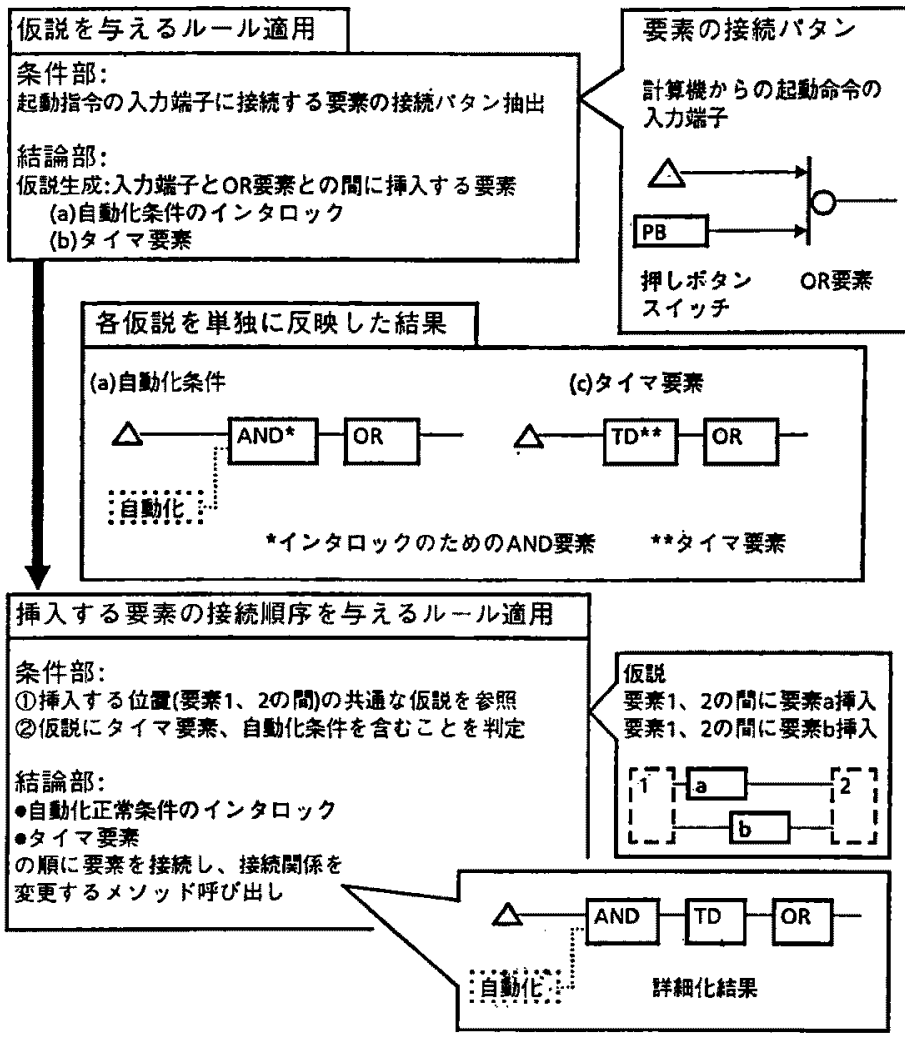

第 5 图ロシック詳細化のプロセスの例

一方，制御系の設計では，第 1 图の例の上うに，值 の切椟兄要素の配置のように，信号の流れが機能圀と 詳細図では異なり，機能図の配置を直接参考にするの が難しい。

したがって，制御系の設計では，詳細図の利用目的 に対し，詳細図を機能的な部分に分割し易いよらに信 号の流れに沿って要素を整列させたり，合理的な要素 の演算順序を与える上で設計者の認識を助けるよらな 図面のレイフゥトに重点を圈く必要がある。京た，機 能困と詳細図之は，要素の接続情報を与えるといら意 味では同等であるが，線図の表現は全く巽なってい る。このように，配置条件は数值的に表現できるもの に限られず多様なるのなっている。したがって，多 様な配直条件を記号により直接表現して利用する知識 処理が有奻と判断した。

4. 綰図レイアウトでの知讙処理方式

(1) 知識の構成

a. 知識のグルーブ化

設計者は大局的に要素の接続関係を把握し，鍵横に 整列させて配䶊できる要素の組を定め，その組の中か
ら要素を選択し，逐次，配置可能な位圆に要素を割り 当ててゆく手順を用いる。この摖，配監済み部分と未 配置部分との間にまたがる配圈条件を利用する必要が ある。この条件を配置の過程で求めることはルールの 条件を複雑にし，同時に，同じ条件をむつルールが多 数存在することになり、ルールを探索する上です奻率 が悪くなる。以上の観点から，知識を以下のクループ に分類してルールとして表わした。

（1）整列可能な要素の組を決定する。

(2)図の最上位置に整列可能な要素の組を選択す る。

(3) ロシックの入カに近い要素から順に演算順序 を考虑して，要素の配瞋順序を決定する。

(4) 複数の入出力端子を持つ要素, 信号線の分岐 がある場合，要素の配監順序を決定する。

ここで，(1)，(2)は要素の配㙺条件を求める知識であ ク，(3)，(4)は要素の配圈順序，位置を求める知識であ る。また(1),(2)の知識は(3)，(4)の知識に先立ち適用す る。一方，(3)，(4)の知識は知識の適用順序を与えすに 配置の過程で要素の接綂バタンに応して選択される。 
さらに（1)，(2)，(4)は線図の見易さ向上させる配置条 件に関するヒューリスティックスを表わしたるのであ り，(3)は再帰的な配置手順を表現したるのである。
第6図に知識の例を示す。本图では知識の種類(1)と (4)の例を示す。

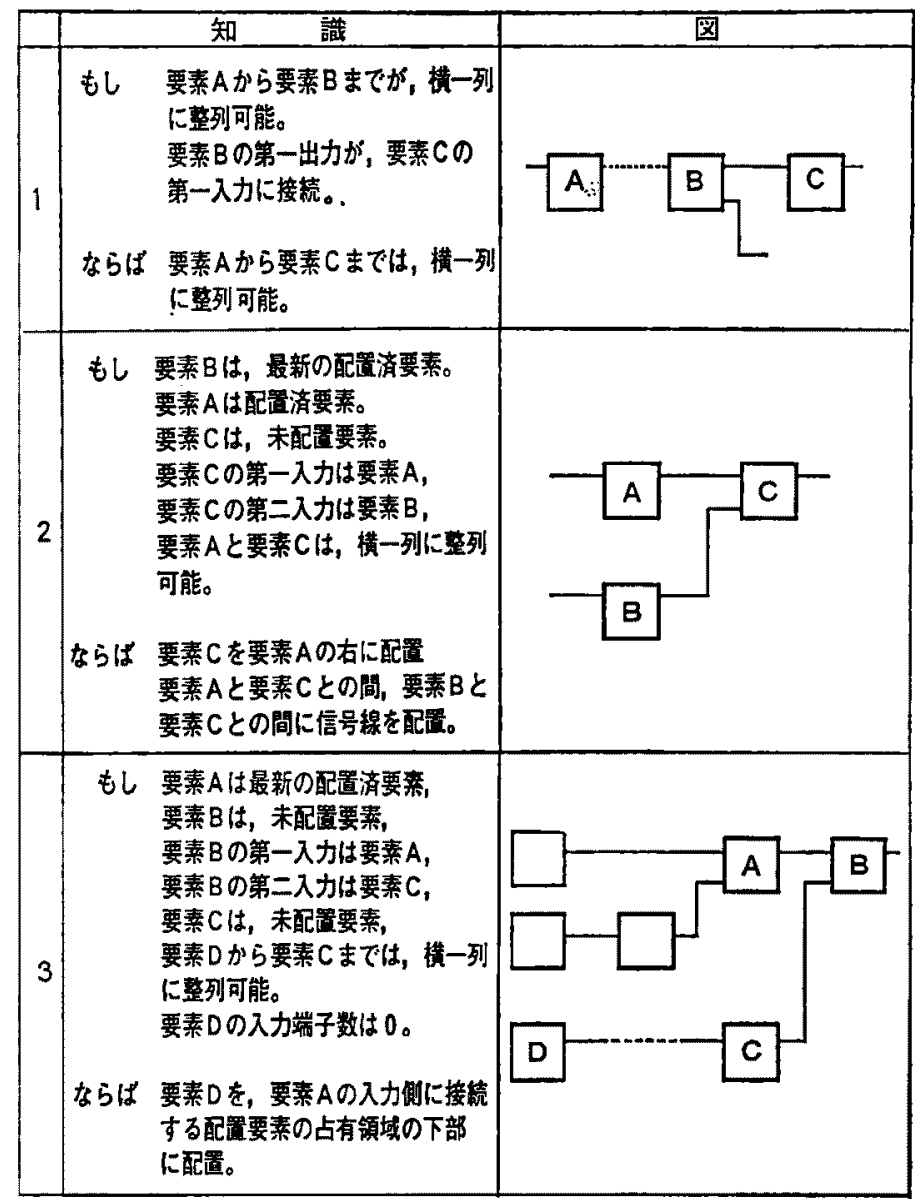

第 6 図 線図レイアウトの知識の例

$b$, 知識の表現

要素の配直条件を求める知識は，复数の要素間の配 䁂条件を与える条件を単位としてルールで表現する。 配贉条件は述語論理型データにより表現する。

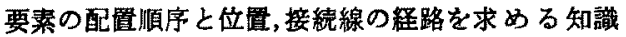
は, 配置済み要素と末配置要素との間の接続関係と配 瞋条件を参照して，次に配置する要素を結論として与 えることができる単位にルールで表現する。

(2)推諭方式

推論の対象とするルールは, 以下の知瀻のタルーブ の適用順序を与える上位の知識により指定する。

(1) 要素の配置条件を求める知識
(2) 要素の配直順序, 位置を求める知識

各知識のタルーブ内では，条件部での制御条件の多 いルールを優先して適用する。これは，要素の同一の 接続バタンに対しては，要素の種類に依らない一般的 な条件をもつルールが先に適用されてしまらことを回 避し，要素の属性を限定する程度の高いルールを優先 するためである。

前述の知識の種類(1)，(2)に対応するルールで，要 秦の接絰関係をフレームの形で取り出して，要素の配 圈条件を述語論理型データの形で求める。

また，知識の種類(3)，(4)に対応するルールでは，最

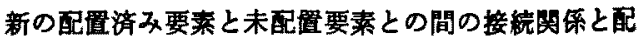


湴条件を検案し，次に配䭪する要案を選択する条件が 成立するかどうかを調べる。さらに，ルールの結論部 では，要素の位管を决定するため自動的にメンッドを 呼び出す。主要なメソッドは

(1) 配固みの要素の占有領域の座標の下限值 の計算

(2) 要素を眍闐する座標值の計算

(3) 要素の出力端子の座標值の計算

(4) 要秦間の接続線の経路決定 である。

（3）線困レイフウトのブロセスの例

ロシック詳細化後の要素の接続バタン，以下の 2 種類のパタンを組み合わせたものとなっている。

(1) 複数の入力信号に対して，多入力一出力の要
素を用いた演算を繰り返して出力信号を求める パタン。

（2）複数の演算の中間結果を，演算の進んだ段階 で再び要素への入力とし，その演算結果から出 力信号を求めるパタ。

操作ブロック図では，シーケンス制御系の主要な機 能の一つであるタイマ動作，誤入力中泾渧の検出動作 などを記述するために，時間要素や記憶要素等により 演算を施される前と後の信号を同時に入力として用い る要素の接繶パタンが多用される。第 7 图はここの接 続パタンに特有な，信号の分岐後再び多入力の論理要 素に入力する部分を配膡する際の線図レイアウトの知 識と、その適用ブロセスを示したものである。

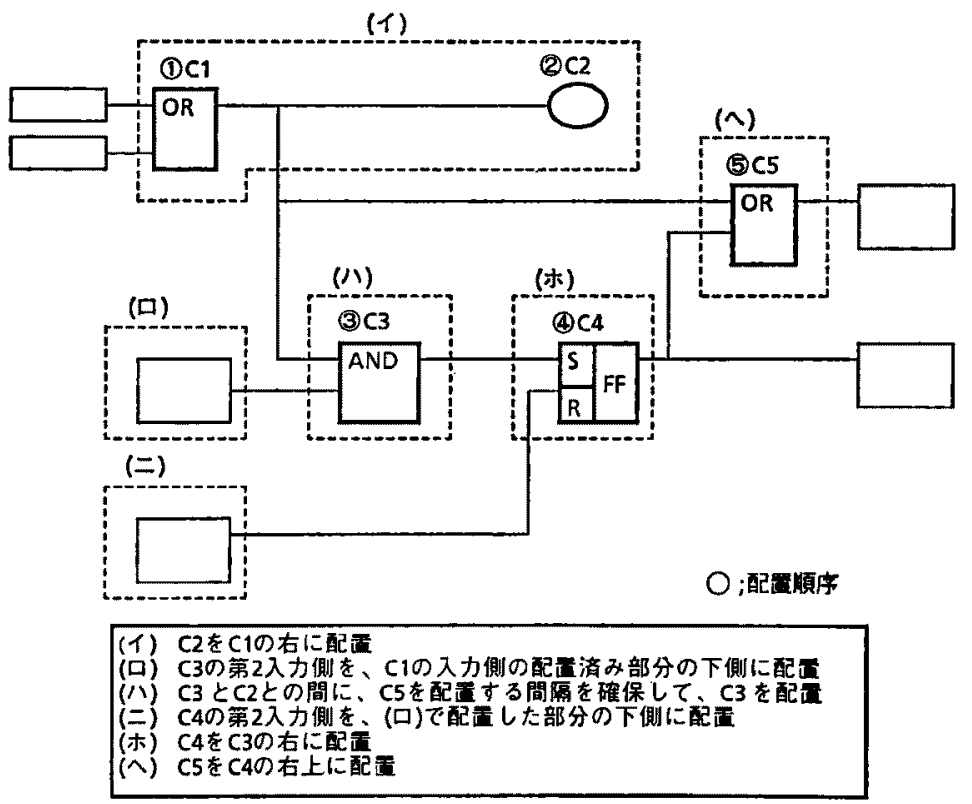

第 7 図線図レイフウトのブロ七スの例

例えば，(1)のブロセスで䔔用するルールは，C1と末 配監の C $2, \mathrm{C} 3, \mathrm{C} 4, \mathrm{C} 5$ との間の次の配直条件を参照 ナる。

- C1とC2は一列に整列可能

- C1とC5は一列飞整列可能

- C1 C $3, \mathrm{C} 4$ は一列に整列可能

さらに，C4かiC 50第 2 入力に努続している要素間 の接繶条件から，C1，C 3，C4，C5の接続構成に「信号 の分岐後再び多入力の論理要素に入力する部分」があ ることが判定された。この結果，C3，C4，C5を配置
する段階で接繶線の交叉を回避するために「１１の右 にC2を整列させて配置する」ことを導く。

以上のよらに，配置済子部分と未配置部分とにまた がる配墱条件を用いることにより，配固が進んだ後の 段階での要素間の干涉の可能性を予湘する条件の記述 が可能となる。

以上の方式は，ネットワーク状に構成された設計対 象の属性を決定する設計過程で，前過程からの設計案 と末決定の設計対象の属性との関係を分析し，次に実 行すべき操作を決定する手法(17)を，要絭の配置といら 
物理的な属性を対象に払張したるのといえる。この手 法では，実行すべき操作を選ぶ根拠を陽に表現するこ とによりトップダウン的に設計過程を棈成できる(18)。 本方式では，配圈条件によりこの根执を与去ており， 配置修正を不要とする配置手順を構成する上で効果的 である。

したがって，本方式は設計対象をブロック図形式で 表現できる配㯰問題について適用可能である。

\section{I. 制御系ロジック自堛变換システム}

前章で説明した知識処理方式に基ついた，発電プラ ントの制御系ロジック自動変換システムの構成につい て説明する。

本システムは, 機能図として制御系統図および操作 ブロック図を，詳細図として制御ロシッック図をおのお の対象とした。基本的な構成を第 8 図に示す。

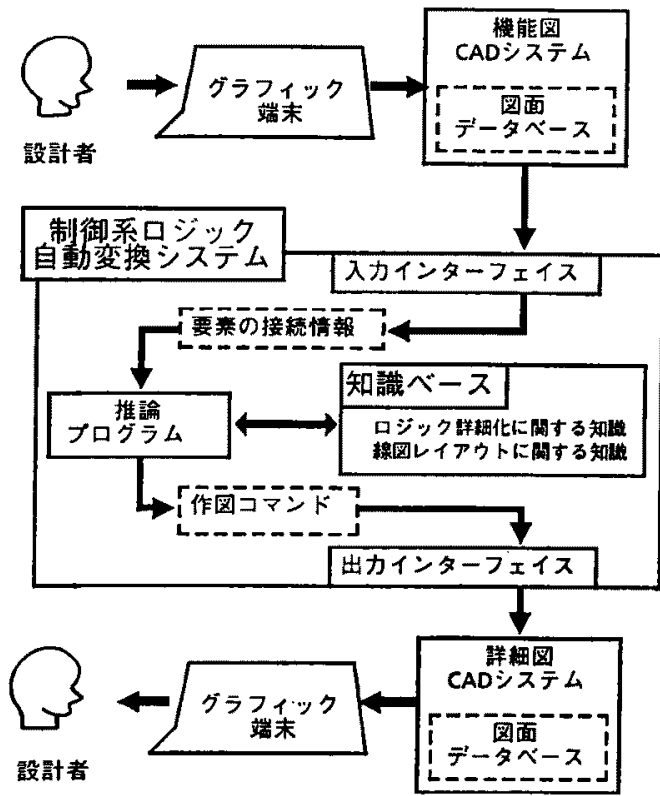

第 8 図制御系ロシック自制変換システムの構成

本システムと設計者との間のインタフェイスには, 図面の作成・俢正·登録を初めとする図面データベース 管理譏能をるつ製図用CADシステム(3)を活,用した。設 計者は，CADシステム対話入力機能とクラフィック表 示機能とを利用して, 要素, 倞号線の配置を表示画面 上で指示して図面を作成,修正する。また，要素，信号 線の種類と座標とをあわせた作図コマンドをあらかじ めデータフォイルに格納して扰きこれをCADシステ
ムに入力することにより，図面を作成する。 本システムの主要な楧成要素の概要を以下に示す。

(1) 推論ブログラム

推論プログラムには,ルールおよび述語論理型のデ 一タとフレームとを併用した推論に適した，沉用知識 処理システム構策支援ツールを採用した (10)。

本ッールは，以下の特徵により，推論実行時の効辛 化を図っている。

(1) ルールの条件部で検索する述語論理型のデー タ,フレームとルールとの関連を、あらかじめ ネットワークに変換する。

（2）上位の知識により与克にれた探索戦略とルー ル間の閏連性とに基づきネットーク探索ブロ グラムを作成する。推論央行時には，本プロク ラムを実行する。ここで、ルール間の関連性と は，すべてのルールに対する条件部の重襩状況 である。異なるルールです，同一の条件判定を 含むすのについては，その判定結果が共有でき るよら探索ブログラムが構成される。

(2) 知識ベース

第 1 表にルールの分類と数を示す。

ロショク詳細化での知識ベースには，制御系統図， 操作ブロック図のおのおのについて，前章で分類した 知識のグループに従い，ルールを格納した。さらに， 要素の秏類を表わすクラスフレーム20件，新たな要素 のフレームを作成するィソッド1件，扰よび要素の接 続情報を変更するメソッド 3 件を記述するクラスフレ ームす併わせて知識べースに格納した。

\begin{tabular}{|c|c|c|}
\hline \multirow[b]{2}{*}{ 知識のグルーブ } & \multicolumn{2}{|c|}{ ルール数 } \\
\hline & $\begin{array}{l}\text { 制御 } \\
\text { 系統図 }\end{array}$ & $\begin{array}{l}\text { 操作 } \\
\text { ブロク困 }\end{array}$ \\
\hline \multicolumn{3}{|l|}{ ロシック詳細化 } \\
\hline カタルール & 1 & 1 \\
\hline 要素の捕入 & 21 & 24 \\
\hline 分披位置の変更 & 3 & 3 \\
\hline 分岥と要素の逭加 & 16 & 16 \\
\hline \multicolumn{3}{|l|}{ 線図レイアウト } \\
\hline 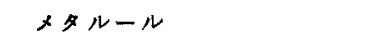 & & 1 \\
\hline 整列可能な要素の組の決定 & & 4 \\
\hline $\begin{array}{l}\text { 最上位置に整列可能な要素の } \\
\text { 組の決定 }\end{array}$ & & 10 \\
\hline $\begin{array}{l}\text { 単数の入出力端子, 分岐をるこ } \\
\text { 要素の配置 }\end{array}$ & & 4 \\
\hline 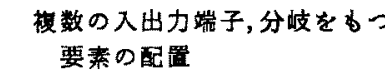 & & 34 \\
\hline
\end{tabular}


線図レイフウトでの知識ベースに目しては，ロジ ク詳細化後の制御ロシック因で要素の接続情報の棈造 は、制御系統図と缲作ブロック図では同等であり, 両 者に共通して適用するルールを格納した。さらに，要 素,接続線の座標を求めるメソッド61件を記述するク ラスフレームも併わせて知識ベースに格納した。

（3）入出力情報

入力情報は，機能図の要素の種類，信号の種類等の 要素の属性, 要素間の接続関係である。機能図の図面 データベースからロジック变換螌囲に対応する, 要素 の接结倩啹を抽出して作成する。出力情報は，詳細図 を作図するCADシステムの作図コマンドである。

\section{V. 適用結果とその評価}

\section{1. 嗃用対象とその結果}

開発した制御系ロジックの自動変換システムを，出 力100万 $\mathrm{kWe}$ 級の発電ブラントの制御系設計图面の一 部分のロジック变換に試験的に適用した。

以下, 結果について述べる。

（1）対象とした図面の概要

ロシック変換の対象とした制御系統図には，演算要 素のほか，図面間の接続子を合わせて39件の要素を含 んでる。対象とした制御系統図は，次の機能を記述 している。
(1)多重系構成による給水流量信号の入力
(2) 給水流量目標値と流量信号値との偏差信号の 単位变乗演算と, その結果の出力

ロシック変換の対象とした操作ブロック図は，同様 に22件の要素を含み，主に次の機能を記述している。

(1) シーケンス起動可能·禁止条件の入力

第 9 図に操作ブロック図の例を示す。

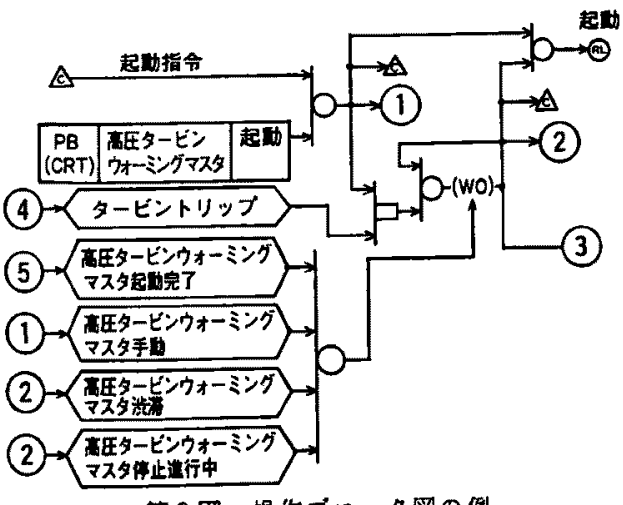

ロジック変换システムへの入力は, 実際の設計で用 いるロジック変换範国と同一の部分の要素の接続情報 とした。

(2) 適用結果とその評洒

制御系統図を制御口ジッタ図にロジック変換した結

果，要素40件を新たに付加した。

操作ブロック四を制御ロジック図にロジック変換し た結果，要素26件を新たに付加した。

第10图に，操作ブロック図から制御ロシック园への ロジック変換結果を示す。本図で*を付した要素が新 たに付加したすのである。

以上のロシック変換に要した処理時間は，ロジック 詳紐化で約 $5 \mathrm{~min}$, 線図レイフウトで約 $15 \mathrm{~min} か ら ら 25$ minであった。的 1 Mipsの演算処理能力をむつワー クステーション型計算機を用いて処理を㬰行した。

以上の適用結果を，発電システムの制御設計に10年 程度の経験をるつ設計者による設計結果と比较して, 評価した。

適用結果では，設計者が機能図を参照して詳細図を 作成する段階で付加した要素がすべて付加されてお り、設計者による変換結果と同等であった。また，機 能図に記載されたコネントで，詳細図に転記すべきる のはすべて記載された。

一方，史設計での詳細図に対し，本システムでは付 加されなかった情報は以下の3点である。

(1) 制御信号名,制御条件等の詳細なコメント

(2) 要素間の演算順序

(3）制御信号のデータをを格納するフドレス

これらの情報は，詳細設計を坦当する設計者が制御演 算プロク゚ラムを設計・製作するために，詳細図に付加 される必要がある。これらは，ロジック変換により得 られた複数の詳細図を参照して図中に記载されるすの であり，前記のCADシステムを用いた設計者の介入 が必要である。

\section{V. 結雷}

設計者の知識を反映して、プラントの制御系ロシッ クを機能図から詳細図人と自動的に変換する，知識処 理方式を開発した。本方式の特幑は次の 2 点にある。

(1) ロシック詳細化では，知識を 3 ダループに分

割して，クループ間の適用順序を上位の知識で 与えることにより，汎用的な知識を組み合わせ て，個ヶの要素の接繶構成に適したロジック詳 細化手順を構成する。また，複数の要素を追加 する際に接続順序を決定する知識の競合を解消 


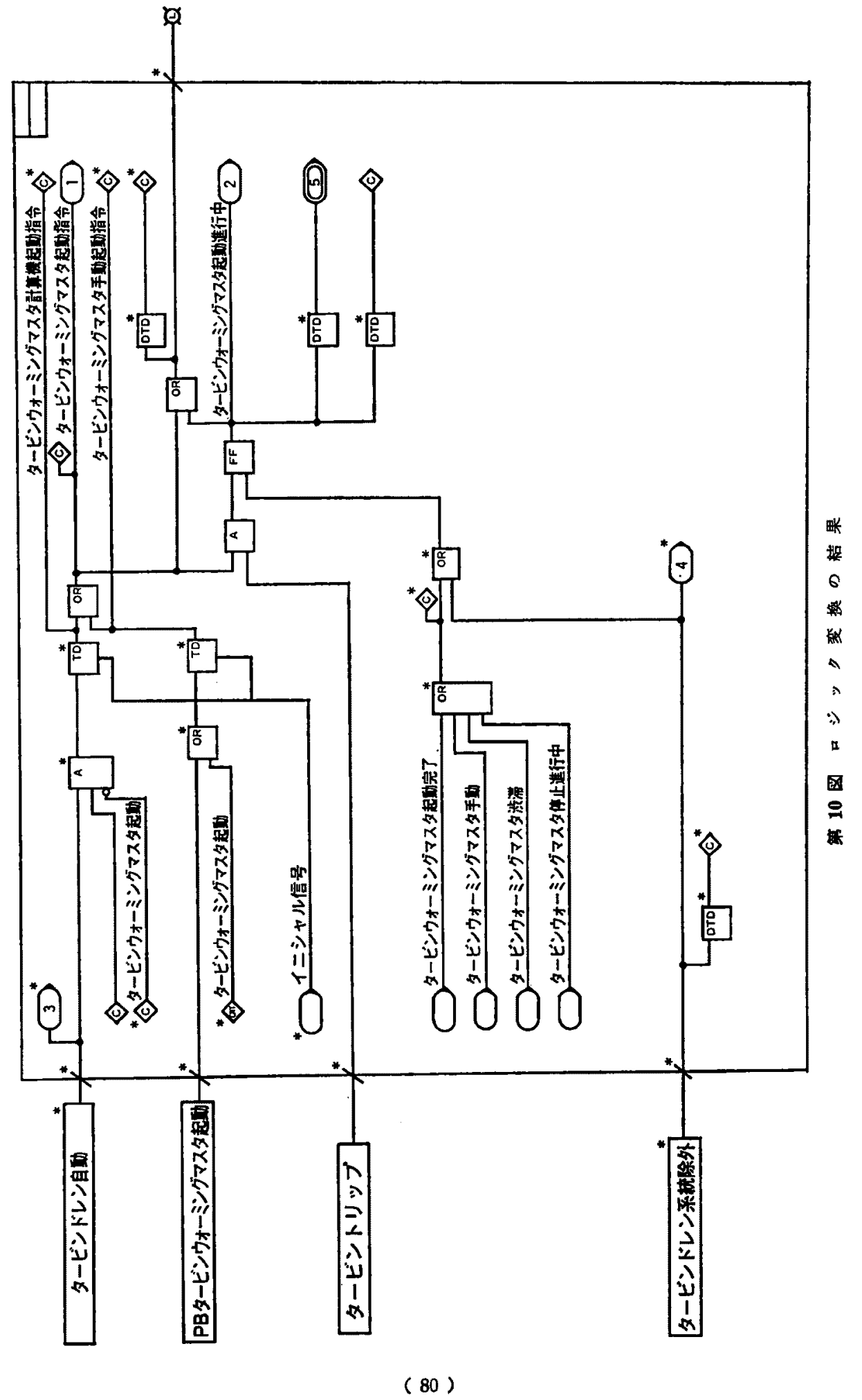


するため，個々に追加する要素の種類と追加位 直を仮説として与えるルールと，椱数の仮説を るとに各要素間の接続順序を与えるルールとに 分離して知識を記述し，知識の沉用性を高的 た。

（2）線図レイフウトでは，多捸な要素の接綍バ夕 ンに応じた配直条件をレイアウトに反映するた め，配固条件を迸出する知識と，配膡条件に基 づき要素を配置する知識とをルールにより表現 して利用した。特に，要素を配直するルールで は, 配笽済みの要素と末配置の要素との間の接 続関保と，两者にまたがる配置条件とを考虑し て，配看が進んた段階での要素間の千涉の可能 生を予剆して，干步を回避するレイアウトを求 める。

また，本方式に基づいた制御系ロジック自動変換シ ステムを，発電ブラントの制御系設計四面を対象に試 用評価した。知識ベースには，約 150 件の知識をルー ルの形で蓄えた。制御系統図から制御口シック図，物 よひ操作ブロック図から制御ロジック図へのロジック 変换について，設計者に上る設計結果と同様の結果が 得られた。これらの変換結果と推論過程より、本方式 の特である、(1)汎用的な知識を組み合わせたロジッ ク詳紐化と，(2)多様な配居条件を反映した線図レイア ウトが有効に夹現されていることを確認した。

なお，本方式は，ブロック四形式でシステムの機能 仕様を記述し，機能仕様図にシステムの構成要素を付
加しながら詳細仕様を設計するエンジニアリング分野 でのロジック変换に適用可能である。また，本報で例 としたような発電ブラントに限らず，化学ブラント， 水処理ブラント等の制衙系設計支援に本方式は抬張可 能である。

\section{一考文献一}

(1) 三宅雅夫, 他 : 日立評論，70[5]，23 28（1980).

(2) 朝日隆一, 他：原子力学会「昭62年会」要旨集, D40.

(3) Imbro, E.V., et al.: Trans. Am. Nucl. Soc., 59, 254 $\sim 260$ (1989).

(4) 小林克己, 他 : 日立漷倫，62[7]，5１0（1980）.

(5) Wiesbaden, S.W.: Automatisierungs-tech. Praxies, 28[6], 282 290 (1986).

（6）林達男,他：原子力学会「昭63年会」要旨集，A31.

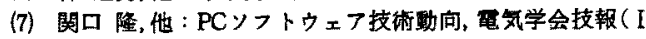
部)第142号, (1985)。

（8）古田勝久，他：電気誌，106[2]，105 112（1986）.

（9）三巻達男，桑原洋: “制御用計算機におけるリフルタイム 技術”，(1986)，二ロナ社.

(10) KOMODA, N., et al.: IEEE Computer, C-17[12], $73 \sim 83$ (1984)

(11) 山崎正实，他 : FUJITSU，39[5]，336 341 (1988).

(12) 西山保, 他：計矵と制御，27[10]，923～924 (1988).

(13) Watanabe, $\mathrm{T}$, et al.: IEEE/ACM Proc. $23 \mathrm{rd}$ Design Automation Conf., 608 614 (1986).

(14) MAY, M., et al.: Computer-aided Des., 15[3], 115 122 (1983).

(15) 宾鍋俊彦，他：情報処理学会第33回全国大会2R-5,(1985).

(16) 和田裕, 他: 原子力学会「昭63秋の大会」予稿炛、A47.

(17) Mostow, J.: The AI Magazine, Spring, 44 55 (1985).

(18) MCDERMOT, J.: Artificial Intelligence, 19[1], 42 65 (1982).

(19) 船橋誠膞，他：日立評論，70[5]，103 110 (1988).

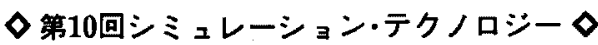

$$
\text { コンファレンス }
$$

主催 日本シミュレーショソ学会

势本会はか関連学茄会

会期 1991年6月19日(水)，20日(木)

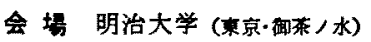

分事(予定):シミュレーション言吾と技法,システムのモデ ル化とモデル娭徰、シミニレータとハードウェフ,リ フルタイムシミュレーション, 知瀻工学とシミュレ ーション, 計算力学, 画像処理・信号処理, ロボティッ クス, CAD·CAM·CAI, 物理·化学·電気・通信·鹤

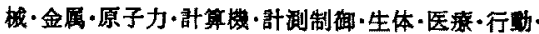
教育·交通運谕・社会·程済·亚境等諸分野への心用

申込方法 発表希望者は所定の「発表申込寒」に題目，氏名(共者

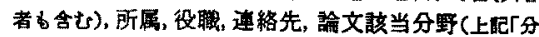
野」のどれに腒するか)，300字程度の発表要旨等を衭

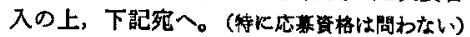

な扰，発表 1 件につ発表申远金8,000内が必要 だす。（ただし，論文集 1 冊，掖刷20部䁬呈）

申込楴切1991年 2 月 2 日 (土)

原楼楴切”4月20日(土)

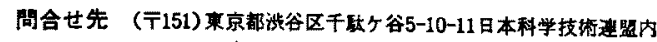
日本シミュレーション学会事務局 (03-5379-1236; FAX 03-225-1814) 